\title{
Coeliac disease and small bowel carcinoma
}

\author{
SimON KeNWRIGHT* \\ M.R.C.P. \\ Department of Gastro-enterology, Frenchay Hospital, Bristol
}

\begin{abstract}
Summary
Small bowel carcinoma can occur in association with villous atrophy in the jejunum. In most reported cases there is doubt as to which of these represents the primary lesion. These cases are reviewed here. A further case is reported in which a carcinoma developed in a patient known to be suffering from coeliac disease for some years, although he was not on a gluten-free diet for the time preceding the diagnosis of carcinoma. On dietary restriction he remains well at 2-year follow-up. Possible aetiological factors are discussed.
\end{abstract}

\section{Introduction}

The association between coeliac disease and small bowel reticulosis has been well reviewed in recent years, but the incidence of small bowel carcinoma has not received as much attention. It has been suggested that malignancy anywhere in the body may be associated with villous atrophy (Creamer, 1964). Others feel that this relationship is sometimes no more than co-incidental (Harris et al., 1967). There is strong evidence that carcinoma of the oesophagus has a significantly higher incidence in coeliac disease (Harris et al., 1967; BrzechwaAdjukiewicz et al., 1966; Wright \& Richardson, 1967). Harris et al. (1967) in describing thirty-four malignancies in over 200 cases of coeliac disease and idiopathic steatorrhoea, also report a number of instances of the occurrence of carcinoma elsewhere in the alimentary tract, but they found no small bowel carcinomas, and only four reports in the literature. Brzechwa-Ajdukiewicz et al. (1966) reviewed five case reports and added a further three reports of small bowel carcinomas occurring in patients suffering from steatorrhoea and another earlier report has been found in the French literature (Kissel et al., 1965). In some of these reports the evidence for a diagnosis of a coeliac syndrome preceding the carcinoma is inconclusive. Authors reporting series of small bowel malignacies often make no mention of malabsorption or mucosal

\footnotetext{
*Present address: Department of Gastro-enterology, Northwick Park Hospital, Watford Road, Harrow, Middlesex.
}

appearances. Brunt, Sircus \& Maclean (1969), in reviewing small bowel malignancies at Edinburgh over a 10-year period, found no evidence of malabsorption in those patients shown to have a carcinoma. This was in marked contrast to the fifteen cases of abdominal lymphoma where unequivocal evidence of malabsorption was found in thirteen, and villous changes in all but one of these. Lee (1966) reviewed the surgically resected primary malignant tumours of the small intestine over a similar period from the Western Infirmary Glasgow. Of the lymphoid tumours, only two of nine cases showed a normal mucosa, but in only one of nine cases of adenocarcinoma was there subtotal villous atrophy. Another case showed mild partial villous atrophy of the ileum. Neither of these patients with carcinoma gave a history of preceding malabsorption. Blackwell (1961) described two patients with small bowel carcinoma and partial or complete villous atrophy. Evidence of malabsorption was also found at this time, but there was no history suggesting a preceding malabsorption syndrome. In reviewing twelve other cases of small bowel carcinoma he found only two cases with mild changes of atrophic jejunitis.

The purpose of this communication is to review the literature on small bowel carcinoma in coeliac disease and to add another case report, in which there seems no doubt that the coeliac disease preceded the development of a jejunal adenocarcinoma.

\section{Case history}

The patient was first admitted to Frenchay Hospital in September 1962, when he was 30 years old, for the investigation of intermittent diarrhoea. He gave a history strongly suggestive of childhood coeliac disease, but he had been relatively well from the age of 14 years until this present illness.

Physical examination at this time revealed no abnormality. He weighed $72.6 \mathrm{~kg}(160 \mathrm{lb})$ and there was no history of recent weight loss. His haemoglobin level and blood film were normal. A 3-day faecal fat excretion was $\mathbf{4 1} \mathrm{g}$ and xylose absorption test gave a low result $(3.8 \mathrm{~g}$ urinary excretion in 
$5 \mathrm{hr}$ following a $25 \mathrm{~g}$ loading dose). Barium meal and follow-through examination showed a very rapid transit through the small intestine, but no other abnormality. A Crosby capsule jejunal biopsy showed subtotal villous atrophy.

As a result of these investigations he was started on a gluten-free diet. On this his diarrhoea cleared and he put on weight, and by 1967 he weighed $88.9 \mathrm{~kg}$ $(176 \mathrm{lb})$. With the help of a reducing diet he lost $9.5 \mathrm{~kg}(21 \mathrm{lb})$. From 1967 he also gradually reintroduced gluten into his diet. In November 1969 he complained that since June he had suffered four attacks of nausea with epigastric distension. The symptoms lasted about 1 day and were relieved by vomiting. He had continued to lose weight, despite stopping his reducing diet. His only other complaint was of looseness of his stools, but these had returned to normal following the resumption of his glutenfree diet (September 1969).

On re-admission in November 1969 he weighed $73.9 \mathrm{~kg}(163 \mathrm{lb})$ and was pale, but no other abnormality was found on examination. His temperature was normal, but on 2 days during the first week rose to $99^{\circ} \mathrm{F}$. His stools were strongly positive for occult blood. His haemoglobin was $10.4 \mathrm{~g} / 100 \mathrm{ml}$ $(71 \%)$ with moderate hypochromia. The serum folate was low at $3.2 \mathrm{ng} / \mathrm{ml}$, but other blood tests, including electrolytes, urea, liver function tests, calcium, plasma viscosity and $\mathbf{B}_{12}$ were all well within normal range. A micropaque barium meal and follow-through examination showed the proximal 6 in. of the jejunum to be considerably dilated with flocculation of the medium (Fig. 1).

Malignancy was suspected and at laparotomy (Mr R. Celestin) a ring tumour of the jejunum was found, just below the duodeno-jejunal flexure. A wedge resection was performed, removing the area involved, with its regional lymph nodes. The spleen was noted to be about three quarters of the normal size. Histological examination showed the tumour to be a well-differentiated adenocarcinoma. A mucosal specimen from beyond the immediate vicinity of the tumour showed partial villous atrophy. No tumour was seen in the lymph nodes. Postoperatively he did well and was re-started on a gluten-free diet, with folate and iron supplements. On this treatment he put on $9 \cdot 1 \mathrm{~kg}(20 \mathrm{lb})$ weight within 6 months of operation. He developed a keloid at the site of his scar, but otherwise remained well. His blood count has remained normal. His immunoglobulin levels estimated 6 months after surgery were normal, the $1 \mathrm{gA}$ being $184 \mathrm{mg} / 100 \mathrm{ml}$. (normal $290 \pm 120 \mathrm{mg} / 100 \mathrm{ml}$ ). These were not estimated pre-operatively. He was last seen in outpatients in May 1972.

In 1968, his mother, who was then 53 years old, was found to be suffering from coeliac disease. This

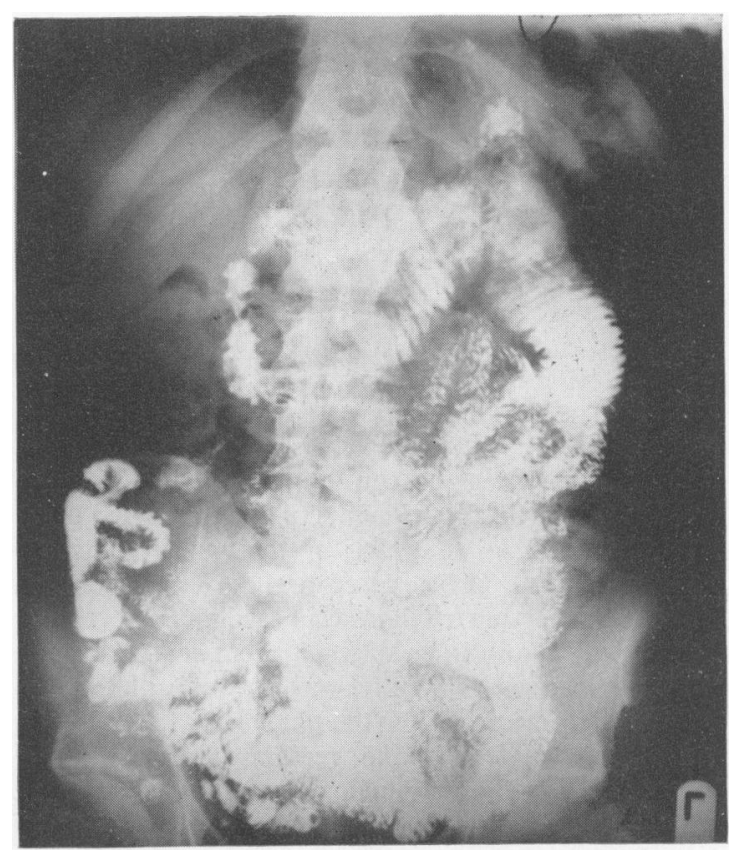

FIG. 1.

diagnosis was made at another hospital and waș based on a very suggestive history, subtotal villous atrophy on biopsy and a good response to a glutenfree diet.

\section{Discussion}

A jejunal biopsy showing subtotal or total villous atrophy and symptomatic improvement on a glutenfree diet are widely accepted necessary criteria for the diagnosis of coeliac disease.

Any attempt to separate small bowel carcinomas producing villous atrophy from those arising in patients with coeliac disease is liable to error. Ideally, the diagnosis of coeliac disease should be made at least 2 years before the diagnosis of carcinoma. If these strict criteria are to be accepted, the present report would seem to be the first of a coeliac patient developing a small bowel adenocarcinoma. A further eight reports have been found where the diagnosis of coeliac disease is based on a suggestive history of several years' duration, with evidence of malabsorption and steatorrhoea for at least 2 years before the diagnosis of small bowel carcinoma. A favourable response to a gluten-free diet and a childhood history are regarded as additional confirmatory findings, although Hindle \& Creamer (1965) felt that a similar proportion of patients with primary and secondary coeliac syndromes responded to dietary restriction. These reports have been summarized in Table 1. 
TABLE 1. Reports of small bowel carcinoma and villous atrophy in patients with strong evidence for preceding coeliac disease

\begin{tabular}{|c|c|c|c|c|}
\hline Report & Sex & Age* & Evidence for diagnosis of coeliac disease & Site \\
\hline Ogilvie \& Shaw (1955) & $\mathbf{M}$ & 40 & 'Steatorrhoea for years'; abdominal discomfort & Duodeno-jejunal junction \\
\hline $\begin{array}{l}\text { Case records-Massachusetts } \\
\text { General Hospital (1958) }\end{array}$ & $\mathbf{M}$ & 60 & $\begin{array}{l}11 \text { yr history of intermittent diarrhoea; clinical } \\
\text { laboratory evidence of malabsorption with } \\
\text { steatorrhoea }\end{array}$ & First part of jejunum \\
\hline Moertel \& Hargreaves (1961) & $\mathbf{M}$ & 68 & $\begin{array}{l}11 \text { yr history with } 8 \text { yr clinical and laboratory } \\
\text { evidence of intermittent steatorrhoea; } \\
\text { brother treated for malabsorption for } 8 \mathrm{yr}\end{array}$ & Mid-jejunum \\
\hline $\begin{array}{l}\text { Girdwood et al. (1961) } \\
\text { Shearman et al. (1962) }\end{array}$ & $\mathbf{M}$ & 50 & $\begin{array}{l}\text { Short stature }(1.57 \mathrm{~m}) \text { with bowed legs. } 8 \text { months } \\
\text { after onset of diarrhoea as adult, clinical and } \\
\text { laboratory evidence of malabsorption and } \\
\text { flat jejunal mucosa; } 5 \text { months later } \\
\text { anaplastic carcinoma found at laparotomy }\end{array}$ & $\begin{array}{l}70 \mathrm{~cm} \text { below duodeno- } \\
\text { jejunal flexure }\end{array}$ \\
\hline Fric et al. (1963) & $\mathbf{F}$ & 44 & $\begin{array}{l}29 \text { yr history of intermittent diarrhoea and } \\
\text { anaemia; } 5 \text { yr clinical and laboratory evidence } \\
\text { of malabsorption; improvement on gluten- } \\
\text { free diet, but relapsed }\end{array}$ & Jejunum \\
\hline Kissel et al. (1965) & $\mathbf{F}$ & 44 & $\begin{array}{l}\text { Suggestive childhood history with intermittent } \\
\text { diarrhoea and evidence of malabsorption as } \\
\text { adult; postoperative improvement on } \\
\text { gluten-free diet }\end{array}$ & Mid small intestine \\
\hline \multicolumn{5}{|l|}{ Brzechwa-Ajdukiewicz et al. (1966) } \\
\hline Case 6 & $\mathbf{M}$ & 65 & $\begin{array}{l}\text { Suggestive childhood history; } 8 \text { yr intermittent } \\
\text { diarrhoea as adult }\end{array}$ & $\begin{array}{l}90 \mathrm{~cm} \text { below duodeno- } \\
\text { jejunal flexure }\end{array}$ \\
\hline Case 7 & $\mathbf{F}$ & 72 & $\begin{array}{l}\text { Intermittent diarrhoea for } 37 \mathrm{yr} ; 7 \text { yr laboratory } \\
\text { and radiological diagnosis; marked } \\
\text { improvement on gluten-free diet }\end{array}$ & $\begin{array}{l}10 \mathrm{~cm} \text { distal to duodeno- } \\
\text { jejunal flexure }\end{array}$ \\
\hline Present case & $\mathbf{M}$ & 37 & $\begin{array}{l}\text { Suggestive childhood history; intermittent } \\
\text { diarrhoea as adult; } 7 \text { yr before diagnosis of } \\
\text { carcinoma, found to have steatorrhoea and } \\
\text { subtotal villous atrophy on jejunal biopsy. } \\
\text { Patient improved on gluten-free diet. } \\
\text { Mother diagnosed as adult coeliac disease }\end{array}$ & First part of jejunum \\
\hline
\end{tabular}

*At time of diagnosis of carcinoma.

In some patients, villous atrophy has been found in association with a jejunal carcinoma, but there is little or no evidence of a malabsorption syndrome preceding the onset of malignancy. The reports of Joske (1960) and Blackwell (1961) and Lee (1966) fall into this group. In other reports the duration of malabsorption before the diagnosis of the carcinoma is too short to warrant a diagnosis of preceding coeliac disease, despite some supporting evidence. These reports include one of the patients of Girdwood, Delamore \& Williams (1961) and case number 1 of Brzechwa-Ajdukiewicz et al. (1966). Hennessy \& Ralston (1969) report a patient in whom the initial diagnosis was coeliac disease with some response to a gluten-free diet and an intestinal biopsy showed total villous atrophy. However, later the patient was found to have an ileocaecal carcinoma and, following resection of this, she was able to tolerate a normal diet and a further intestinal biopsy showed only minor abnormalities.

Carcinoma of the jejunum and ileum is very rare and probably account for only about $1 \%$ of all gastro-intestinal carcinomas (Southam, 1963). Haffner \& Semb (1968) and Eversen (1969) provide recent reviews. This rarity has not yet been explained but increases the significance of the nine reports in the table. Unfortunately, there are no adequate data on the prevalence of coeliac disease, particularly in its sub-clinical form. At $1: 5000$, an approximate figure for the clinical disease, a hundred-fold increase in the incidence of small bowel carcinoma would still only result in some two or three cases per thousand coeliac patients. There seem to be no definite features distinguishing small bowel carcinoma occurring in patients with coeliac disease from those without this association. Mean ages for the 
diagnosis of small bowel carcinoma range from about 50 to 60 years, and that of the patients in Table 1 is 53 years. The patient reported here is the youngest of these. The sex incidence of small bowel cancer also varies from series to series, usually ranging from equality to being twice as frequent in men. Of the nine patients here, three were women. The most common site distal to the duodenum for a small bowel adenocarcinoma also varies in different series, and although several series have reported a higher incidence in the jejunum than in the ileum (Everson, 1969), Brookes, Waterhouse \& Powell (1968) felt that there was no particular prevalence in any one site. Of the nine patients in Table 1 , the first $90 \mathrm{~cm}$ of the jejunum was involved in at least six, whereas in those with less strong evidence of underlying coeliac disease, the carcinomas are spread more evenly throughout the small bowel. There is a suggestion, therefore, that the part of the bowel most affected in coeliac disease is also the most common site for carcinoma. Yet this evidence is much less striking than it is in regional enteritis, where many more small bowel carcinomas have been described and nearly all of them have been in the ileum (Wyatt, 1969). Furthermore, in regional enteritis, the mean age at diagnosis of malignancy, about 43 years, is also younger.

In coeliac disease there are both local features in the jejunum and generalized disturbances of the immunological system which might predispose to malignant change. Epithelial cell maturation seems to be defective (Creamer, 1962) and there is evidence of an abnormally high epithelial cell turnover during clinical relapse (Croft, Loehry \& Creamer, 1968). Chronic inflammation, infection and an increased absorption of carcinogens through a damaged mucosa have also been suggested as factors. Kenrick \& Walker-Smith (1970) suggest that the raised IgA level found in some patients with coeliac disease could be a response to antigens iz the diet, and it has been suggested that a rising serum $\operatorname{IgA}$ in patients on a gluten-free and milk-free diet might herald the onset of a lymphoma (Asquith, Thompson \& Cooke, 1969). In recent years evidence of an underlying immunological disturbance in coeliac disease has accumulated, although the nature of this disturbance is far from clear. An increased incidence of gastrointestinal malignancy has been reported in association with other dysgammaglobulinaemias. In addition, impaired lymphocyte reactivity against tumour cells has been found in patients with coeliac disease and it has been suggested that this, in association with the abnormal cell turnover in the epithelium, could contribute to a higher incidence of malignancy (Maclaurin, Cooke \& Ling, 1971).

An appreciation of possible aetiological factors could help in the separation of a high-risk group and in the earlier diagnosis of malignant change. Those who failed to keep to a gluten-free diet are possibly at a greater risk (Harris et al., 1967), but patients with a malignancy sometimes still show a favourable response on returning to the diet, and a patient who has been responsive in the past will not necessarily always remain responsive, even in the absence of malignancy. In the present patient, the most important pointers to the onset of malignancy were the continued weight loss, the development of an anaemia with strongly positive tests for occult blood in the stools and the radiological appearances. Yet in patients with small bowel carcinoma, even repeated radiological examinations may fail to show any definite abnormality. Exfoliative studies have not yet been shown to be helpful. In addition to immunoglobulin estimations, phytohaemagglutininduced lymphocyte transformation might be helpful in the diagnosis of a reticulosis complicating coeliac disease (Blecher et al., 1969). As lymphoma of the small bowel is probably at least ten times more common than carcinoma in coeliac disease it is probable that the latter will usually be diagnosed when the former is suspected. The present case emphasizes the possibility of a good prognosis when the diagnosis is made in good time.

\section{Acknowledgments}

I should like to thank Dr J. M. Naish for his permission to publish details of this patient, and for his help in the preparation of this report.

\section{References}

Asquith, P., Thompson, R.A. \& Cooke, W.T. (1969) Serum immunoglobulins in adult coeliac disease. Lancet, ii, 129.

BLACKWELL, J.B. (1961) Gastroenterological Society of Australia: Malabsorption in the presence of primary carcinoma of the small bowel. Gut, 2, 377.

BleCher, T.E., BrzeChWA-AJduKIEWICZ, A., McCarthy, C.F. \& READ, A.E. (1969) Serum immunoglobulins and lymphocyte transformation studies in coeliac disease. Gut, $10,57$.

Brookes, V.S., Waterhouse, J.A.H. \& Powell, D.J. (1968) Malignant lesions of the small intestine: a 10-year survey. British Journal of Surgery, 55, 405.

Brunt, P.W., Sircus, W. \& MAClean, N. (1969) Neoplasia and the coeliac syndrome in adults. Lancet, $\mathbf{i}, 180$.

Brzechwa-Ajdukiewicz, A., McCarthy, C.F., Austad, W., Cornes, J., Harrison, W.J. \& Read, A.E. (1966) Carcinoma, villous atrophy and steatorrhoea. Gut, 7, 572.

Case Records of the Massachusetts General Hospital (1958) Case 44362. New England Journal of Medicine, 259, 491.

Creamer, B. (1962) Dynamics of the mucosa of the small intestine in idiopathic steatorrhoea. Gut, 3, 295.

Creamer, B. (1964) Malignancy and the small intestinal mucosa. British Medical Journal, 2, 1435.

Croft, D.N., Loehry, C.A. \& Creamer, B. (1968) Small bowel cell loss and weight loss in the coeliac syndrome. Lancet, ii, 68.

Everson, T.C. (1969) Cancer of the Digestive Tract (Ed. by T. C. Everson and W. H. Cole), pp. 75-85. Butterworth, London. 
Fric, P., Bednar, B., Niederle, B. \& Lepsik (1963) Jejunal adenocarcinoma in a woman with non-tropical sprue. Gastroenterology, 4, 330.

Girdwood, R.H., Delamore, I.W. \& Williams, A.W. (1961) Jejunal biopsy in malabsorptive disorders of the adult. British Medical Journal, 1, 319.

HAFFNER, J.F. \& SEMB, L.S. (1968) Malignant tumours of the small intestine. Acta Chirurgica Scandinavica, 135, 543.

Harris, O.D., CoOKe, W.T., Thompson, H., \& Waterhouse, J.A.H. (1967) Malignancy in adult coeliac disease and idiopathic steatorrhoea. American Journal of Medicine. 42, 899.

Hennessy, W.B. \& Ralston, M. (1969) Gastroenterological Society of Australia: Ileocaecal carcinoma and the coeliac syndrome. Gut, 10, 951.

Hindle, W. \& Creamer, B. (1965) Clinical picture accompanying a flat small intestinal mucosa. British Medical Journal, 2, 458.

Joske, R.A., (1960) Primary carcinoma of the jejunum with atrophic jejunitis and intestinal malabsorption. Gastroenterology, 38, 810.

KeNRICK, K.G. \& WALKeR-Smith, J.A. (1970) Immunoglobulins and dietary protein antibodies in childhood coeliac disease. Gut, 11, 635.
Kissel, P., Rauber, G., Barraucand, D., Marchal, Cl. \& Leclere, J. (1965) Documents cliniques. Archives des Maladies de l'appareil digestif, 54, 945.

LEE, F.D. (1966) Nature of the mucosal changes associated with malignant neoplasms in the small intestine. Gut, 7, 361.

Maclaurin, B.P., Cooke, W.T. \& Ling, N.R. (1971) Impaired lymphocyte reactivity against tumour cells in patients with coeliac disease. Gut, 12, 794.

Moertel, C.G. \& Hargraves, M.M. (1961) Co-existence of adenocarcinoma of the jejunum and non-tropical sprue. Journal of the American Medical Association, 176, 612.

Ogilvie, T.A. \& SHAw, H.M. (1955) Primary tumours of the small bowel. British Medical Journal, 1, 142.

Shearman, D.J.C., Girdwood, R.H., Williams, A.W., \& Delamore, I.W. (1962). A study with the electron microscope of the jejunal epithelium in primary malabsorptive disease. Gut, 3, 16.

Southam, J.A. (1963) Primary malignant tumours of the jejunum and ileum. British Journal of Surgery, 50, 393.

Wright, J.T. \& Richardson, P.C. (1967) Squamous carcinoma of the thoracic oesophagus in malabsorption syndrome. British Medical Journal, 1, 540.

WyATT, A.P. (1969) Regional enteritis leading to carcinoma of the small bowel. Gut, 10,924 . 